\title{
PATTERNS OF THE DISTRIBUTION OF THE DEMAND OF END-CONSUMERS AMONG RETAILERS IN THE ZONE OF THEIR RESIDENCE
}

\section{Andrii GALKIN*, Vitaliy ZAYTSEV**, Viktor SHYSHKIN***, Larysa OBOLENTSEVA****, Yuliia POPOVA*****}

*O.M. Beketov National University of Urban Economy in Kharkiv, Faculty of Transport System and Technologies, Kharkiv, UKRAINE, e-mail: galkin.tsl@gmail.com

**Kharkiv University of Technology "STEP", Kharkiv, UKRAINE e-mail: vitaliy.zaytsev@khai.edu

***Zaporizhzhia National University, Department of Entrepreneurship, Organization Management and Logistics, Zaporizhia, UKRAINE e-mail: shishkin.vip@ukr.net

****O.M. Beketov National University of Urban Economy in Kharkiv, Department of Tourism and Hospitality, Kharkiv, UKRAINE e-mail: larysa.obolentseva@gmail.com

\footnotetext{
*****State University of Infrastructure and Technologies, Department of Business Logistics and Transportation Technologies, Kyiv, UKRAINE e-mail: yuli-p@ukr.net
}

\begin{abstract}
The rapid development of retail and e-commerce is forcing marketing and logistics to be competitive and adapt to the demands of end-customers. At the same time, accurately determining the demand for goods allows to better understand customers and plan deliveries. The purpose of this article is to study the change in patterns of probability of choosing the option to purchase goods among end-consumers with and without the presence of e-commerce. The study consisted of research buyers, determining the probability of purchasing goods from "consumer basket" in the traditional way and over the Internet, which is considered for the example of one of the Kharkiv districts. The results develop e-commerce potential in Ukraine and are intended to determine the motives of consumers when choosing a shopping option.
\end{abstract}

Keywords: end-consumers, logistics, zone, service, nonlinearity factor, slope factor.

JEL Classification: M31, M39, C93, D19, L69.

\section{Introduction}

With the advent of computer technology, e-commerce has become an integral part of almost every area of human life. More and more consumers buy goods through the Internet, and commercial organizations somehow use the capabilities of this network in carrying out their activities (Gorokhova and Mamatova, 2020).

The globalization of e-commerce requires companies in various industries to radically restructure the classic logistics system, which was based on the service of retail trade, taking into account the geographic location of online outlets. Online trading, eliminating the distance factor, does not eliminate borders and interstate differences in regulatory rules. Thus, it is not reduced only to the accelerated delivery of goods to the buyer and it provides the organization rigid control over all chain of goods promotion, taking into account requirements of merchants, their suppliers, and buyers (Sharma, Chen and Luk, 2018).

The development of sales strategies in e-commerce is associated with the need to solve a number of complex problems (Wodecki, 2020). A user who saves his time and has visited the e-shop can, according to his wishes, choose the product very quickly, pay for it quickly and, of course, also wants to get it quickly (Mixed-Use Properties: A Convenient Option for Shoppers, 2019). 
Most companies in Ukraine today have their own Internet sites that present the company and provide effective two-way communication with consumers (Pursky, et al., 2019). In addition to the representative function of Internet sites, companies widely use a variety of Internet applications for more effective interaction with suppliers and partners (Chornopyska and Bolibrukh, 2020). It becomes important for the enterprise to evaluate the unknown capabilities of competitors, predict their actions, and analyze the degree of competitive threat (Lusch, Serpkenci and Orvis, 2015).

In this regard, analysis of the purchase options has the following main goals and objectives: determining the type of competitive market (Tkachenko, et al., 2020); identification of actual and potential competitors, determination of the number, type and size of competing firms (Koval, et al., 2020); calculation of market share occupied by competitors; characteristics of the intensity and direction of competition (Balandina, et al., 2018); a management concept of a cities (Bajdor and Starostka-Patyk, 2021); a modeling framework to forecast urban goods flows (Comi, 2020); identifying the strengths and weaknesses, strategies and evaluating the competitiveness of their competitors' products (Fesenko, et al, 2018); analysis and forecasting of competitor's behavior in the market and his reaction to various marketing actions (Halkin, et al., 2019); and agent modeling of online store activities (Selivanova, et al., 2020)

Certain parameters of existing models and methods do not provide a systematic approach to determining retailer visiting probability vs e-commerce in current market or trade zone. Previously the utility of retailer based on generalized costs of end-consumers was assessed (Halkin, 2020) only for walking traditional shopping in store. Here, the e-commerce option will be added to the research area.

The research question is: How the distribution of demand would be changed with added new retailer e-commerce option or would there be no changes at all?

The purpose of this article is to study the change in patterns of probability of choosing the option to purchase goods among end-consumers without and with the presence of e-commerce.

\section{$1 \quad$ Methodology}

\subsection{Method of determining the probability of demand}

The process of consuming goods is closely linked to the concept of process of consumption. The cost of actions in the process of consumption of goods was estimated using the formula presented in Halkin (2020). Traditional shopping deals with physical movement to store and back and trade service inside of it. In e-commerce option, the physical attendance of retailer is missing. End-consumer chooses goods via Internet and receives delivery of goods in the final stage. Both options can be chosen, especially in today's pandemic circumstances.

The work includes study of the area of demand formation at the initial stage, establishment of areas of residence of consumers, major competitors, and geographic features of the area, in accordance with the method proposed by Galkin, et al. (2020). Based on these data, a matrix of probability of choosing the option of consumption by end-consumers from different areas of residence was generated.

The research interest lies in the conditions under which the end user will choose one option over another, for example, online option instead of traditional shopping. It is also interesting to know how to change the existing probabilities of choosing retailers when adding an Internet option.

The systematic approach allows to distribute material flows across retailers (Fig. 1).

The total consumer demand in the $z$ - service area for the $m$-th product for the analyzed period is:

$$
Q_{m z}=\sum_{J=1}^{J} \sum_{w=1}^{W}\left(N_{\omega z} \cdot\left(\sum_{m=1}^{M} Q_{\omega z M}^{\prime}\right)\right)
$$

where $N_{\omega z}$ is the number of end-consumers living in the $\omega$-th building area, people; $Q_{\omega z M}^{\prime}$ the rate of consumption of goods on average per 1 buyer living in the $w$-th building area for the analyzed period, $\mathrm{kg}$ /inhabitant; $\omega$ the number of consumer's zones, $\omega=$ $1,2, \ldots, I ; j$ the number of retailers in the trade urban zone, $j=1,2, \ldots, J$; and $\mathrm{m}$ is the goods type, $m=1$, $2, \ldots, M$. 


\begin{tabular}{|c|c|c|c|c|}
\hline \multicolumn{3}{|c|}{ Output flow of goods of the selected supplier } & \multicolumn{2}{|c|}{ Other suppliers } \\
\hline $\begin{array}{l}\text { Distribution } \\
\text { channels }\end{array}$ & $\begin{array}{c}\text { The volume of goods } \\
\text { sold through } \\
\text { a retailer }\end{array}$ & $\begin{array}{l}\text { The volume of } \\
\text { sales of goods } \\
\text { via the Internet }\end{array}$ & $\begin{array}{r}\text { Sales volume of goo } \\
\text { other retail chains } \\
\text { lected retaile }\end{array}$ & $\begin{array}{l}\text { ds from } \\
\text { and se- } \\
\text { ss }\end{array}$ \\
\hline \multirow{2}{*}{$\begin{array}{l}\text { The probability } \\
\text { of choosing a distri- } \\
\text { bution channel }\end{array}$} & $P_{z \omega j}-?$ & $P_{m \omega e^{-}} ?$ & $P_{m \omega o}-?$ & \\
\hline & \multicolumn{4}{|c|}{ End-consumers } \\
\hline
\end{tabular}

Figure 1. The probability of choosing a retailer by the consumer, where (Source: Own study):

$P_{z \omega j}$ is the the probability of visiting the $j$-th retailer by end-consumers from $\omega$-th building zone when buying the $m$-th product,

$P_{m \omega e}$ the probability of choosing the Internet channel by the end-consumer from $\omega$-th building zone when buying the $m$-th product, and

$P_{m \omega o}$ is the probability of choosing other retailers in addition to those located in the shopping area when buying the $m$-th goods.

In a closed system, the total demand for the $m$-th product is defined as the sum of demand for all retail outlets and demand that is realized through the Internet:

$$
Q_{m z}=Q_{m z j}+Q_{m z e}+Q_{m z o}
$$

where:

$Q_{m z j}$ is the quantity of goods sold through the retailer, $\mathrm{kg}$;

$Q_{m z e}$ the quantity of sales of goods via the Internet, $\mathrm{kg}$;

$Q_{m z o}$ the quantity of goods sold through other retailers in this residence zone, $\mathrm{kg}$; and

$z$ is the number of trade urban zones, $z=1,2, \ldots, Z$.

The quantity of sales of the $m$-th product through $j$-th retailer is defined as:

$$
Q_{m z j}=\sum_{\omega=1}^{W}\left(P_{z \omega j} \cdot N_{\omega z} \cdot\left(\sum_{m=1}^{M} Q_{\omega z M}^{\prime}\right)\right)
$$

The volume of sales of $M$-th goods via the Internet in the considered shopping area can be determined using the formula:

$$
Q_{m z e}=\sum_{w=1}^{W}\left(P_{m \omega e} \cdot N_{\omega z} \cdot\left(\sum_{m=1}^{M} Q_{\omega z M}^{\prime}\right)\right)
$$

The quantity of $m$-th goods sold through other retailers in this trading area for a period of time is determined using the formula:

$$
Q_{m z o}=Q_{m z}-Q_{m z j}-Q_{m e z}=Q_{m z} \cdot P_{m \omega o}
$$

where $P_{m \omega o}$ is the probability of choosing retailers in addition to those located in the shopping area when buying the $m$-th goods.

Every consumer's choice involves costs. Based on the total losses for each alternative choice of retailer, the market share that will be sold for it is determined. Market share owned by retailer $j$ in the sale of the $m$-th product is determined as follows:

$$
E_{m z j}=\frac{Q_{m j z}}{Q_{m z}}=\frac{\sum_{\omega=1}^{W}\left(P_{m \omega j} \cdot N_{\omega z} \cdot\left(\sum_{m=1}^{M} Q_{\omega z M}^{\prime}\right)\right)}{\sum_{j=1}^{J} \sum_{\omega=1}^{W}\left(N_{\omega z} \cdot\left(\sum_{m=1}^{M} Q_{\omega z M}^{\prime}\right)\right)}
$$

Market share owned by Internet sales of $m$-th goods in the residence zone is found using the formula:

$$
E_{m z e}=\frac{Q_{m e z}}{Q_{m z}}=\frac{\sum_{\omega=1}^{W}\left(N_{\omega z} \cdot P_{m \omega e} \cdot\left(\sum_{m=1}^{M} Q_{\omega z M}^{\prime}\right)\right)}{\sum_{j=1}^{J} \sum_{\omega=1}^{W}\left(N_{\omega z} \cdot\left(\sum_{m=1}^{M} Q_{\omega z M}^{\prime}\right)\right)}
$$


Market share of the producer of the $m$-th product, which is sold in the residence zone $z$ by other market participants, is given as:

$$
E_{m z o}=\frac{Q_{m z o}-Q_{m j z}-Q_{m e z}}{Q_{m z}}=\frac{\sum_{j=1}^{J} \sum_{j=1}^{W}\left(N_{\omega z} \cdot\left(\sum_{m=1}^{M} Q_{\omega \Sigma M}^{\prime}\right)\right)-\sum_{j=1}^{W}\left(P_{m \omega e} \cdot N_{\omega} \cdot\left(\sum_{m=1}^{M} Q_{\omega z M}^{\prime}\right)\right)-\sum_{j=1}^{J} \sum_{\omega=1}^{W}\left(P_{m \omega j} \cdot N_{\omega} \cdot\left(\sum_{m=1}^{M} Q_{\omega z M}^{\prime}\right)\right)}{\sum_{j=1}^{J} \sum_{j=1}^{W}\left(N_{\omega z} \cdot Q_{\omega \Sigma M}^{\prime}\right)}
$$

The research hypothesis is based on the choice of the retailer by a certain group of customers, based on generalized costs that they will incur as a result of their choice. Each end-consumer choice leads to costs generation. The generalized costs of visit by residents of the $\omega$-th neighborhood of the $z$ zone who visit the $j$-retailer (Galkin, Dolia, and Davidich, 2017) are given as:

$$
\Theta_{\text {total }}^{w j}=\Theta_{1}^{\omega j}+\Theta_{2}^{\omega j}+\Theta_{3}^{\omega j}+\Theta_{4}^{\omega j}+\Theta_{5}^{\omega j} \rightarrow \min
$$

where $\Theta_{1}^{\omega j}$ is the monetary expression of shopping time spent on purchases, UAH.; $\Theta_{2}^{\omega j}$ the monetary costs on the purchase of goods in the $j$-retailer, $\mathrm{UAH}$; $\Theta_{3}^{\omega j}$ the monetary expression of the energy (fatigue) spent on purchases, UAH; $\Theta_{4}^{\omega j}$ the monetary expression of other non-price factors, $\mathrm{UAH}$; and $\Theta_{5}^{\omega j}$ is the cost related to delivery, UAH.

Increasing end-consumer losses will reduce the frequency of choice of logistics system and market share that belongs to it and vice versa.

For successful practical implementation of the research, we divided our method into three stages:

1) Preliminary analysis, which includes the method of boundaries of the store's service area setting (Balandina,, et al., 2019) and socioeconomic data collection. This stage will provide information on end-consumers and their behavior (incomer, consumer basket, age, gender, etc.) and on competitor pool (stores, products, prices, services, etc.).

2) Conducting an experiment and processing the data. This stage is aimed at collecting information on demand probability for stores in this area according to the method presented in Halkin (2020). Online shopping will be included in the calculation as well. An approach for this will be presented further.
3) Comparison of the results obtained and conclusions will be presented in the end. At the last stage, probability of visiting off- and online stores will be compared. The influence of online shopping on overall demand distribution will be determined. Patterns of distribution of the demand of end-consumers among retailers in the zone of their residence will be found.

\subsection{Technology of online shopping}

The total time taken to make a purchase via the Internet is calculated by the formula:

$$
T_{k}^{\text {purch }}=T_{k}^{\text {comp }}+T_{k}^{\text {mov }}
$$

where $T_{k}^{\prime \text { mov }}$ is the walking time to receive the goods, hrs and $T_{k}^{\text {comp }}$ is the working at the computer time, hrs.

The number of calories a person consumes when shopping online is calculated by the formula:

$$
\begin{aligned}
& \mathrm{KCal}_{\text {our }}^{I}=T_{k}^{\text {mov }} \cdot \mathrm{KCal}_{h}^{\text {mov }}+T_{k}^{\text {cmp }} \cdot \mathrm{KCal}_{h}^{\text {comp }}= \\
& T_{k}^{\text {mov }}(B M R / 24) \cdot M E T_{\text {walk }}+T_{k}^{\text {comp }} \cdot(B M R / 24) \cdot M E T_{\text {comp }}
\end{aligned}
$$

where $K C a l_{\text {ovr }}^{I}$ is the number of calories a person consumes when buying goods online (working on PC, tablet, cell phone, etc.), kcal; $M E T_{\text {walk }}$ the metabolic equivalent of task (while walking), kcal; $M E T_{\text {comp }}$ the metabolic equivalent of task (while working at a computer), kcal.; and $B M R$ is the basic metabolic rate in $24 \mathrm{hrs}$, kcal.

In BMR calculations, the Mifflin-St. Jeor formula was used for different sexes (Mifflin, 1990). When calculating MET, reference data from the following sources were used: Jetté, Sidney, and Blümchen 
(1990) and Ainsworth, et al. (2000). The cost of human energy was estimated using the formula presented in Halkin (2018) and Galkin, et al. (2020).

\section{Results}

\subsection{Experiment}

To study the patterns of consumption of goods via the Internet, six online stores were selected that specialized in delivering products to the consumer. All of them were characterized by different costs of the "consumer basket," web page interfaces, range, and cost of delivery. Online stores such as "Rost", "Tavria B", "Produktoff", "Metro", "Vitok" and "Gastronom" were presented. An example of one of the online stores is presented in Fig. 2.

Information on the range and cost of delivery is presented in Table 1.
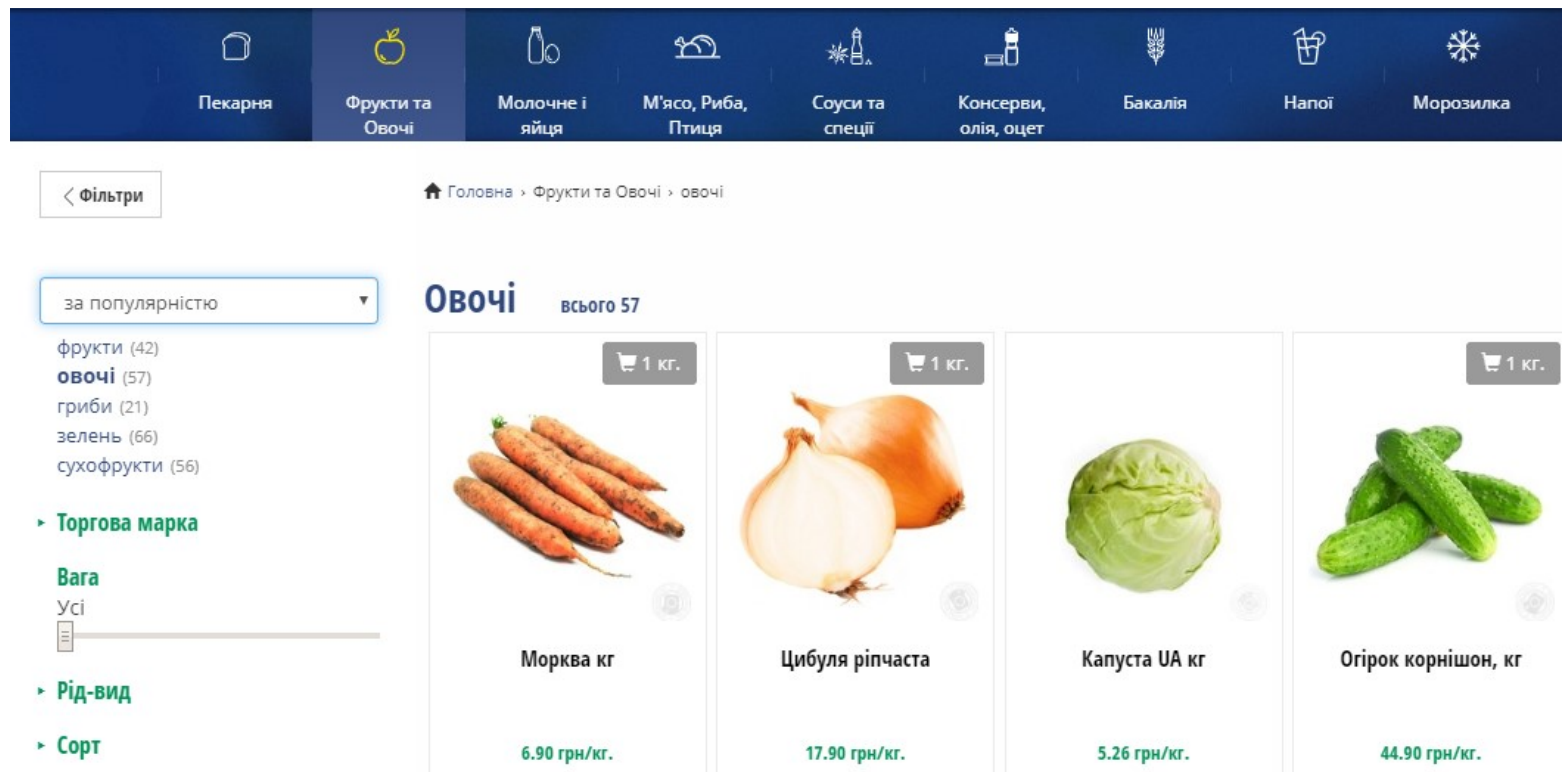

Figure 2. Example of an online store interface (Source: https://metro.zakaz.ua/)

Table 1. General information about online stores (Source: Own study)

\begin{tabular}{|l|c|c|c|c|c|c|c|}
\hline \multicolumn{1}{|c|}{ Online store } & A & B & C & D & E & F & Average meaning \\
\hline Delivery cost, UAH & 15 & 25 & 26 & 23 & 12 & 50 & 25.17 \\
\hline Assortment, units & 1830 & 22,870 & 11,250 & 10,000 & 1360 & 1960 & - \\
\hline
\end{tabular}

At the next stage, respondents were invited to make purchases online. The market of food products included in the consumer basket was considered as the labor market. Shopping mobility was considered as a leisure time action. The consumer basket is an approximate estimated set, the range of goods that characterizes the typical level and structure of monthly (annual) consumption of a person or family. This set was used to calculate the minimum consumer budget (subsistence level), based on the value of the consumer basket at current prices.

The consumer basket also serves as a basis for comparing estimated and real levels of consumption, as well as a basis for determining the purchasing power of currencies. The participants of the experiment had to go to the website of the online store and add to the "basket" the products included in the consumer basket, place an order for delivery, and after 
a while receive the order at the place of residence. Delivery time itself was not tracked. The main indicators were the time and number of calories burned.

Time costs were determined by timing. Walking time is defined as a constant for all online stores, as the walking time to get the delivery at the door or at the entrance will be the same in all cases.
The results of time spent are presented in Table 2.

The results of calorie expenditure according to the time spent on the computer and the Mifflin-St. Jeor formula (Mifflin, 1990) are presented in Table 3.

The cost of time of the buyer in monetary terms and energy costs of the consumer in monetary terms as a result of the purchase via the Internet are presented in Table 4.

Table 2. Time-consuming results (Source: Own study)

\begin{tabular}{|c|c|c|c|}
\hline Online store & $\begin{array}{c}\text { Working time at the computer } \\
\text { hrs }\end{array}$ & $\begin{array}{c}\text { Walking time } \\
\text { hrs (const) }\end{array}$ & $\begin{array}{c}\text { Online shopping time } \\
\text { hrs }\end{array}$ \\
\hline A & 0.23 & 0.02 & 0.25 \\
\hline B & 0.30 & 0.02 & 0.32 \\
\hline C & 0.37 & 0.02 & 0.38 \\
\hline D & 0.22 & 0.02 & 0.23 \\
\hline E & 0.22 & 0.02 & 0.23 \\
\hline F & 0.18 & 0.02 & 0.20 \\
\hline Average meaning & 0.23 & 0.02 & 0.25 \\
\hline
\end{tabular}

Table 3. Calories consumption (Source: Own study)

\begin{tabular}{|c|c|c|c|}
\hline Online store & $\begin{array}{c}\text { The amount of energy consump- } \\
\text { tion when working } \\
\text { on a computer, kcal }\end{array}$ & $\begin{array}{c}\text { Values of energy expendi- } \\
\text { ture during walking } \\
\text { (const) }\end{array}$ & $\begin{array}{c}\text { Values of energy costs } \\
\text { during online purchases, } \\
\text { kcal }\end{array}$ \\
\hline A & 21.3 & 2.8 & 24.1 \\
\hline B & 27.4 & 2.8 & 30.2 \\
\hline C & 33.5 & 2.8 & 36.3 \\
\hline D & 19.8 & 2.8 & 22.6 \\
\hline E & 19.8 & 2.8 & 22.6 \\
\hline F & 16.7 & 2.8 & 19.5 \\
\hline Average meaning & 23.1 & 2.8 & 25.9 \\
\hline
\end{tabular}

Table 4. Results of consumers' cash expenditures from online purchases (Source: Own study)

\begin{tabular}{|c|c|c|c|}
\hline Online store & $\begin{array}{c}\text { Cost estimate of the amount of } \\
\text { time spent in the process of mak } \\
\text { ing purchases over the Internet, } \\
\text { UAH }\end{array}$ & $\begin{array}{c}\text { Cost estimate of the energy expenditure of } \\
\text { the human body in the process of shopping } \\
\text { via the Internet, UAH }\end{array}$ & $\begin{array}{c}\text { Delivery } \\
\text { cost, } \\
\text { UAH }\end{array}$ \\
\hline A & 8.25 & 0.27 & 40.00 \\
\hline B & 10.44 & 0.34 & 60.00 \\
\hline C & 12.64 & 0.41 & 50.00 \\
\hline D & 7.70 & 0.26 & 50.00 \\
\hline E & 7.70 & 0.26 & 30.00 \\
\hline F & 6.60 & 0.22 & 70.00 \\
\hline Average meaning & 8.89 & 0.29 & 50.00 \\
\hline
\end{tabular}


The cost of $1 \mathrm{hr}$ of the consumer was calculated for the level of the average salary in the country, that is, 8093.35 UAH/month (\$ 300) in Ukraine (Kolodii, 2020).

\subsection{Case study}

The retailer's service area has been set up according the influence of end-consumers (Verroios, Efstathiou and Delis, 2011), trip-based approach (Russo and Comi, 2012), and the geographic characteristics of the territory (Comi, 2020). Considering the influ-

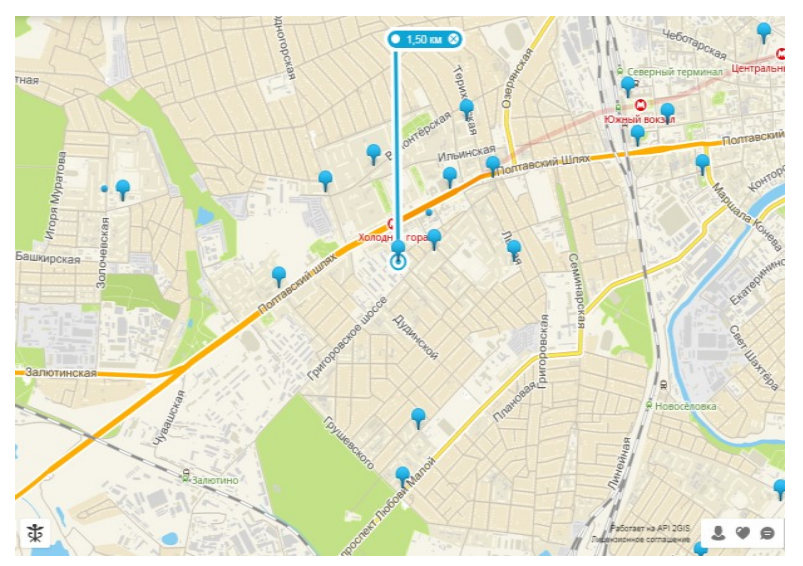

Figure 2. Trading area (Source: Own study)

Presented trading zone analysis (Fig. 3) indicates a large cluster of retailers in it -11 units. Twenty-five retailers are not included in the service area and waived after correction. According to this, it is possible to determine the area, quantity of inhabitants, end-consumers' income and behavior, distances from buildings to each retailer, etc.

In Table 5 is presented distance from the building area to the retailer by air and along the road. The trip-based method was used for customer movement calculations (Galkin, et al., 2019b).

Table 5 shows the distances from neighborhoods to shopping facilities by air and along the road, as well as for the option from the online store $-L$. For the online store, the value of the nonlinearity coefficient was not calculated, so its value is 1 . According to the approach given in Halkin (2020), calculations of other parameters and indicators to determine ence of these parameters will allow adjusting the limits of the retailer's service area, which will more accurately evaluate the demand. The presented zone is the basis for gathering socioeconomic information about the service area (Galkin, et al., 2019a). Taking into consideration the influence of these parameters will allow to adjust the boundaries of the service area. In order to estimate the boundaries, an algorithm is used, which consists of five stages (Halkin, 2020). The area of research was selected according to a previous research (Figs 2 and 3 ). The study area was chosen based on the density of the building and the presence of shopping facilities and an online store.

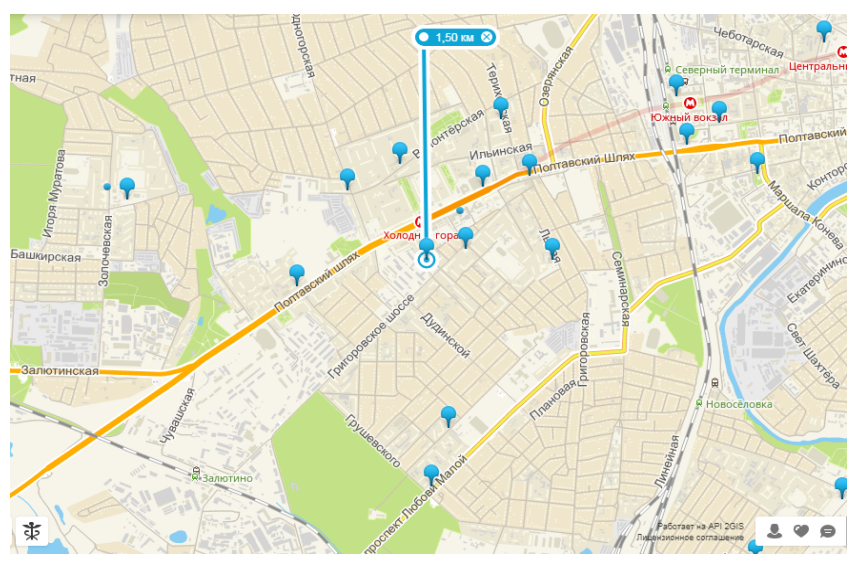

Figure 3. Adjusted trade area:

$1, \ldots, 8$-zones; A, .., G-stores (Source: Own study)

the probability of choosing a purchase option were performed. The results are presented in Table 6 .

For an online store, travel time refers to the time a person spends on getting an order. Its value was equal to $0.02 \mathrm{hr}$, that is, $1 \mathrm{~min}$. The time for sales service for the online store was equal to the time spent working on the computer and was $0.23 \mathrm{hr}$, that is, 15.2 min. The total time for online shopping was equal to $0.25 \mathrm{hr}$.

The results of the calculations showed the effect of the additional option on the probability of choosing existing options:

1) as the number of options increases, the average probability of selecting an option will decrease;

2) e-commerce development in the study area does not exceed $7 \%$, and 
3) e-commerce is less likely because it has a higher cost compared to retailers since it involves delivery.

Retailers $D$ and $G$ will have the highest probability of visiting and retailer $B$ the lowest due to high generalized costs for them - without the Internet delivery channel (according to Halkin, 2020). With the addition of the Internet, retailers $D$ and $G$ remain the most attractive and the least attractive option is $L-\mathrm{e}-\mathrm{com}$ merce. Less-attractive Internet options are associated with the poor development of this market in Ukraine. The study was conducted at the end of 2019 before the coronavirus pandemic. This also contributed to the result. Households traditionally walk to grocery stores (Zatonatska, et al., 2019)

Table 5. Matrix of distances from neighborhood to retailers (Source: Own study)

\begin{tabular}{|c|c|c|c|c|c|c|c|c|c|c|}
\hline \multirow{3}{*}{ Retailer (TO) } & \multirow{3}{*}{ Marking } & \multicolumn{9}{|c|}{ Neighborhood number } \\
\hline & & 1 & 2 & 3 & 4 & 5 & 6 & 7 & 8 & 9 \\
\hline & & \multicolumn{9}{|c|}{ By air, km } \\
\hline Silpo & A & 0.68 & 0.45 & 1.05 & 1.11 & 0.88 & 1.23 & 1.83 & 2.29 & 1.67 \\
\hline Market & B & 1.39 & 0.55 & 0.44 & 1.66 & 0.99 & 0.79 & 2.30 & 2.61 & 1.46 \\
\hline Digma & $\mathrm{C}$ & 0.40 & 0.96 & 1.66 & 0.35 & 0.97 & 1.63 & 1.10 & 1.62 & 1.65 \\
\hline ATB & $\mathrm{D}$ & 0.66 & 0.44 & 1.12 & 0.70 & 0.53 & 1.14 & 1.38 & 1.76 & 1.24 \\
\hline Digma & $\mathrm{E}$ & 1.57 & 0.70 & 0.36 & 1.63 & 0.64 & 0.20 & 2.00 & 2.23 & 0.92 \\
\hline ATB & $\mathrm{F}$ & 1.60 & 0.77 & 0.35 & 1.65 & 0.66 & 0.17 & 2.04 & 2.26 & 0.92 \\
\hline ATB & G & 1.08 & 1.02 & 1.40 & 0.66 & 0.50 & 1.16 & 0.89 & 1.21 & 0.92 \\
\hline Chudo & $\mathrm{H}$ & 1.35 & 1.88 & 2.38 & 0.73 & 1.50 & 2.16 & 0.36 & 0.85 & 1.80 \\
\hline ATB & I & 2.20 & 2.32 & 2.62 & 1.51 & 1.77 & 2.22 & 0.77 & 0.22 & 1.58 \\
\hline Grocer & K & 1.54 & 0.89 & 0.90 & 1.33 & 0.41 & 0.48 & 1.50 & 1.66 & 0.44 \\
\hline Online store & $\mathrm{L}$ & 0.66 & 1.63 & 2.48 & 2.20 & 2.16 & 2.89 & 2.64 & 3.30 & 3.20 \\
\hline \multicolumn{11}{|c|}{ By road, km } \\
\hline Silpo & A & 0.83 & 0.50 & 1.21 & 1.43 & 1.21 & 1.54 & 2.31 & 2.53 & 1.98 \\
\hline Market & B & 1.54 & 0.61 & 0.44 & 2.09 & 1.21 & 1.21 & 2.86 & 2.97 & 1.54 \\
\hline Digma & $\mathrm{C}$ & 0.44 & 1.10 & 1.76 & 0.44 & 0.99 & 1.76 & 1.32 & 2.20 & 2.09 \\
\hline ATB & D & 0.88 & 0.66 & 1.43 & 0.77 & 0.55 & 1.32 & 1.76 & 1.87 & 1.65 \\
\hline Digma & E & 1.76 & 0.77 & 0.50 & 1.76 & 0.77 & 0.22 & 2.20 & 2.53 & 1.10 \\
\hline ATB & $\mathrm{F}$ & 1.76 & 0.88 & 0.50 & 1.76 & 0.77 & 0.22 & 2.20 & 2.53 & 1.10 \\
\hline ATB & G & 1.32 & 1.10 & 1.76 & 0.77 & 0.55 & 1.32 & 1.10 & 1.32 & 1.10 \\
\hline Chudo & $\mathrm{H}$ & 1.65 & 2.20 & 2.64 & 0.77 & 1.76 & 2.42 & 0.44 & 0.99 & 1.87 \\
\hline ATB & I & 2.42 & 2.53 & 3.08 & 1.76 & 1.87 & 2.53 & 0.99 & 0.33 & 1.76 \\
\hline Grocer & $\mathrm{K}$ & 1.76 & 1.21 & 1.10 & 1.43 & 0.55 & 0.50 & 1.65 & 1.87 & 0.50 \\
\hline Online store & $\mathrm{L}$ & 0.66 & 1.63 & 2.48 & 2.20 & 2.16 & 2.89 & 2.64 & 3.30 & 3.20 \\
\hline
\end{tabular}


Table 6. Probability of visiting retailers taking into account the online store (Source: Own study)

\begin{tabular}{|c|c|c|c|c|c|c|c|c|c|c|}
\hline \multirow{2}{*}{ Retailer } & \multicolumn{9}{|c|}{ District number, UAH } & \multirow{2}{*}{$\Sigma$} \\
\cline { 2 - 11 } & 1 & 2 & 3 & 4 & 5 & 6 & 7 & 8 & 9 & \\
\hline 1 & 2 & 3 & 4 & 5 & 6 & 7 & 8 & 9 & 10 & 11 \\
\hline A & 0.0148 & 0.0106 & 0.0076 & 0.0193 & 0.0089 & 0.0051 & 0.0116 & 0.0097 & 0.0013 & 0.0888 \\
\hline B & 0.0112 & 0.0093 & 0.0083 & 0.0156 & 0.0079 & 0.0052 & 0.0099 & 0.0085 & 0.0013 & 0.0772 \\
\hline C & 0.0159 & 0.0088 & 0.0064 & 0.0238 & 0.0086 & 0.0045 & 0.0137 & 0.0110 & 0.0013 & 0.0940 \\
\hline D & 0.0170 & 0.0121 & 0.0083 & 0.0250 & 0.0116 & 0.0058 & 0.0145 & 0.0120 & 0.0016 & 0.1079 \\
\hline E & 0.0114 & 0.0096 & 0.0091 & 0.0167 & 0.0095 & 0.0069 & 0.0111 & 0.0097 & 0.0015 & 0.0854 \\
\hline F & 0.0130 & 0.0110 & 0.0111 & 0.0189 & 0.0112 & 0.0085 & 0.0124 & 0.0108 & 0.0018 & 0.0986 \\
\hline G & 0.0149 & 0.0101 & 0.0077 & 0.0254 & 0.0118 & 0.0059 & 0.0169 & 0.0141 & 0.0018 & 0.1085 \\
\hline H & 0.0121 & 0.0070 & 0.0055 & 0.0214 & 0.0075 & 0.0040 & 0.0173 & 0.0136 & 0.0012 & 0.0897 \\
\hline I & 0.0109 & 0.0070 & 0.0057 & 0.0192 & 0.0078 & 0.0044 & 0.0173 & 0.0193 & 0.0015 & 0.0930 \\
\hline K & 0.0124 & 0.0098 & 0.0085 & 0.0195 & 0.0112 & 0.0069 & 0.0134 & 0.0118 & 0.0020 & 0.0954 \\
\hline L & 0.0089 & 0.0059 & 0.0051 & 0.0131 & 0.0057 & 0.0036 & 0.0095 & 0.0087 & 0.0010 & 0.0614 \\
\hline & 0.1423 & 0.1011 & 0.0832 & 0.2179 & 0.1016 & 0.0607 & 0.1477 & 0.1292 & 0.0163 & 1 \\
\hline
\end{tabular}

\subsection{Determination of an equivalent distance} at which it is still possible to shop online or visit a store in the traditional way

The distance from the area of residence of end-consumers to the retailers is a significant factor that affects the costs when choosing a particular purchase option. Increasing the specified distance reduces the probability. It is advisable to determine the distance at which the end-consumer does not care which option to use - the Internet or traditional purchases. For a distance exceeding this value, the end user should choose e-commerce because its generalized costs will be lower than with traditional purchases. Thus, it is possible to conclude that the generated costs for comparable schemes of distribution (on and off-line) are equal for set group of parameters.

To assess the profitability of online purchases, the sum of two indicators was calculated (energy and time costs in monetary terms):

$$
\Theta_{\text {call }+ \text { time }}^{i j}=\Theta_{1}^{i j}+\Theta_{3}^{i j}
$$

Fig. 4 presents a comparative graph of the total cost of purchase in a regular store and the cost of delivery when ordering products via the Internet (50 UAH), while the cost of the consumer basket was not taken into account (Table A1).

With a delivery cost of $50 \mathrm{UAH}$, the percentage of options below the delivery cost was $93.02 \%$, that is, 80 points; 6 points were above this mark. It is possible to draw a conclusion that at the cost of delivery of 50 UAH to inhabitants of the area of research, it is more favorable to make purchases independently, without using delivery. As the affluence of families and the cost of time increase, the number of end users who choose e-commerce will increase, which is also confirmed in such studies.

Different areas (service areas) have different meanings of the factors that describe them. Thus, the population living in a particular area, the level of their income and the expenditure of residents, and the prices of goods from retailers determine the potential market share (Fatoki, 2020). Taking into account the parameters of cities (density of the transport network, the level of motorization and population density, the size of the service area) allows us to generate technologies for the promotion of freight flows for different levels of the country, region, or city 


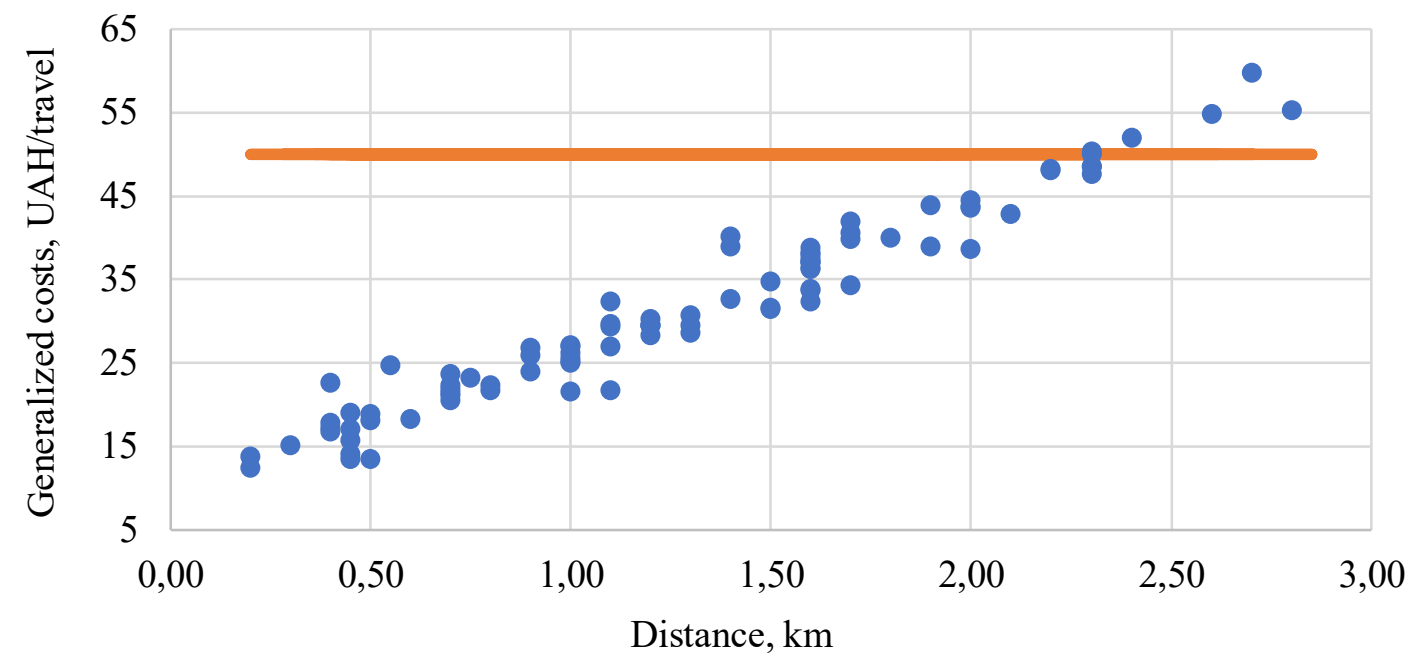

Figure 4. Cost expression of consumer costs associated with the purchasing process (Source: Own study)

- - Total costs (sum of energy and time costs) in monetary terms, UAH

Delivery cost when ordering via the Internet, $\mathrm{UAH}$

The level of organization of the competitive environment can facilitate or complicate the acquisition process and affect the fatigue and emotional state of buyers. The environment is characterized by economic, technological, political, demographic, and natural processes in it.

\section{Discussion and conclusions}

The relevance of this article is proven on the basis of trends in e-commerce and retail around the world. An analysis of methods of forming demand for goods was made. It is established that the change of patterns of probability of choosing the option to purchase goods among end-consumers with and without the presence of e-commerce is a relevant research topic, especially in a pandemic. A scientific method to determine share has been generated.

Research of patterns of demand for goods of visiting off- and online stores were identified. . Six online stores specializing in the delivery of products to the consumer were selected and an imitation of the purchase of goods from the consumer basket was made. The main costs that preceded this type of purchase of goods were calculated, namely, energy, time, and money. In the next stage, a questionnaire survey of Kharkiv residents on the volume of purchases of goods via the Internet was conducted.
In the case study, the study area was selected, which included nine neighborhoods with different forms of development, 10 food supermarkets, and one online store. The formulas were used to determine the direct (costs of purchasing goods from consumer basket) and indirect (time and energy) costs borne by the buyer in a particular type of purchase.

Based on the generated costs, the probability of visiting shopping facilities by residents of the study areas was determined. It was found that this probability changes if we add an online store to the calculation. For example, when calculating without an online store, the probability of visiting store A was 0.0948 , and with an online store, it was 0.0888 , that is, the difference was $6 \%$. Also, the volume of e-commerce development in the study area was set, the value of which did not exceed 7\% (i.e. 6 points).

In contrast to the existing approach, which took into account only the trip-based approach, the proposed one is based on a real calculation of the total costs of end users. The range of variations of the presented factors covers a typical residential area for the Ukrainian city. The proposed approach can be applied to any other city, expanding the range of variations. This study provides a further explanation of the methods of attractiveness of retail visits. The research presented in this article can be implemented in determining the probability of choosing a consumption option: visiting a retailer or ordering goods online. 
The sum of energy and time costs in monetary terms (generalized costs).

Table A1. The amount of energy and time costs in monetary terms, UAH (Source: Own study)

\begin{tabular}{|c|c|c|c|c|c|}
\hline $\begin{array}{l}\text { Measurement } \\
\text { number }\end{array}$ & Route & $\begin{array}{l}\text { Distance, } \\
\mathrm{km}\end{array}$ & $\begin{array}{c}\text { Cost estimation } \\
\text { of human time expenses, } \\
\text { UAH }\end{array}$ & $\begin{array}{c}\text { Cost estimate } \\
\text { of the amount of human } \\
\text { energy consumption, } \\
\text { UAH }\end{array}$ & $\begin{array}{l}\text { General } \\
\text { expenses, } \\
\text { UAH }\end{array}$ \\
\hline 1 & 2 & 3 & 4 & 5 & 6 \\
\hline 1 & $\mathrm{I}-1-\mathrm{A}$ & 0.75 & 21.72 & 1.46 & 23.18 \\
\hline 2 & I-1-B & 1.40 & 36.25 & 2.70 & 38.95 \\
\hline 3 & $\mathrm{I}-1-\mathrm{C}$ & 0.40 & 16.36 & 0.96 & 17.32 \\
\hline 4 & I-1-D & 0.80 & 20.28 & 1.42 & 21.70 \\
\hline 5 & I-1-E & 1.60 & 34.34 & 2.86 & 37.20 \\
\hline 6 & I-1-F & 1.60 & 33.48 & 2.86 & 36.34 \\
\hline 7 & $\mathrm{I}-1-\mathrm{G}$ & 1.20 & 26.30 & 2.07 & 28.36 \\
\hline 8 & $\mathrm{I}-1-\mathrm{H}$ & 1.50 & 32.16 & 2.55 & 34.71 \\
\hline 9 & I-1-I & 2.20 & 44.17 & 3.87 & 48.04 \\
\hline 10 & $\mathrm{I}-1-\mathrm{K}$ & 1.60 & 29.61 & 2.74 & 32.35 \\
\hline 11 & I-2-A & 0.45 & 18.03 & 1.07 & 19.10 \\
\hline 12 & I-2-B & 0.55 & 23.38 & 1.36 & 24.74 \\
\hline 13 & I-2-C & 1.00 & 25.08 & 1.87 & 26.96 \\
\hline 14 & I-2-D & 0.60 & 17.19 & 1.10 & 18.29 \\
\hline 15 & I-2-E & 0.70 & 20.89 & 1.45 & 22.34 \\
\hline 16 & $\mathrm{I}-2-\mathrm{F}$ & 0.80 & 20.82 & 1.54 & 22.36 \\
\hline 17 & $\mathrm{I}-2-\mathrm{G}$ & 1.00 & 25.17 & 1.95 & 27.12 \\
\hline 18 & $\mathrm{I}-2-\mathrm{H}$ & 2.00 & 40.22 & 3.39 & 43.61 \\
\hline 19 & I-2-I & 2.30 & 46.02 & 4.06 & 50.08 \\
\hline 20 & $\mathrm{I}-2-\mathrm{K}$ & 1.10 & 20.00 & 1.73 & 21.73 \\
\hline 21 & I-3-A & 1.10 & 27.27 & 2.04 & 29.30 \\
\hline 22 & I-3-B & 0.40 & 21.45 & 1.15 & 22.60 \\
\hline 23 & I-3-C & 1.60 & 35.78 & 2.99 & 38.77 \\
\hline 24 & I-3-D & 1.30 & 27.30 & 2.15 & 29.45 \\
\hline 25 & I-3-E & 0.45 & 16.13 & 0.96 & 17.08 \\
\hline 26 & I-3-F & 0.45 & 14.86 & 0.92 & 15.78 \\
\hline 27 & I-3-G & 1.60 & 31.28 & 2.59 & 33.87 \\
\hline 28 & $\mathrm{I}-3-\mathrm{H}$ & 2.40 & 47.75 & 4.18 & 51.92 \\
\hline 29 & I-3-I & 2.80 & 50.76 & 4.56 & 55.32 \\
\hline 30 & I-3-K & 1.00 & 19.91 & 1.72 & 21.63 \\
\hline 31 & I-4-A & 1.30 & 28.55 & 2.17 & 30.73 \\
\hline 32 & I-4-B & 1.90 & 40.77 & 3.18 & 43.94 \\
\hline 33 & I-4-C & 0.40 & 15.94 & 0.92 & 16.85 \\
\hline 34 & I-4-D & 0.70 & 20.52 & 1.44 & 21.96 \\
\hline 35 & I-4-E & 1.60 & 35.12 & 2.94 & 38.06 \\
\hline 36 & I-4-F & 1.60 & 34.26 & 2.95 & 37.20 \\
\hline 37 & I-4-G & 0.70 & 19.74 & 1.38 & 21.12 \\
\hline 38 & I-4-H & 0.70 & 22.19 & 1.51 & 23.70 \\
\hline
\end{tabular}


Continuation of Table A1

\begin{tabular}{|c|c|c|c|c|c|}
\hline 1 & 2 & 3 & 4 & 5 & 6 \\
\hline 39 & I-4-I & 1.60 & 33.60 & 2.77 & 36.37 \\
\hline 40 & $\mathrm{I}-4-\mathrm{K}$ & 1.30 & 26.26 & 2.38 & 28.65 \\
\hline 41 & $\mathrm{I}-5-\mathrm{A}$ & 1.10 & 25.18 & 1.82 & 27.00 \\
\hline 42 & I-5-B & 1.10 & 30.35 & 2.09 & 32.43 \\
\hline 43 & $\mathrm{I}-5-\mathrm{C}$ & 0.90 & 25.02 & 1.87 & 26.89 \\
\hline 44 & $\mathrm{I}-5-\mathrm{D}$ & 0.50 & 17.71 & 1.15 & 18.85 \\
\hline 45 & I-5-E & 0.70 & 20.08 & 1.37 & 21.45 \\
\hline 46 & $\mathrm{I}-5-\mathrm{F}$ & 0.70 & 19.17 & 1.37 & 20.54 \\
\hline 47 & $\mathrm{I}-5-\mathrm{G}$ & 0.50 & 17.09 & 1.10 & 18.20 \\
\hline 48 & $\mathrm{I}-5-\mathrm{H}$ & 1.60 & 34.29 & 2.77 & 37.06 \\
\hline 49 & I-5-I & 1.70 & 37.47 & 3.17 & 40.64 \\
\hline 50 & $\mathrm{I}-5-\mathrm{K}$ & 0.50 & 12.51 & 0.95 & 13.46 \\
\hline 51 & I-6-A & 1.40 & 30.35 & 2.36 & 32.71 \\
\hline 52 & I-6-B & 1.10 & 27.86 & 1.83 & 29.68 \\
\hline 53 & I-6-C & 1.60 & 35.31 & 2.94 & 38.25 \\
\hline 54 & I-6-D & 1.20 & 27.42 & 2.16 & 29.58 \\
\hline 55 & I-6-E & 0.20 & 13.12 & 0.64 & 13.75 \\
\hline 56 & I-6-F & 0.20 & 11.84 & 0.60 & 12.44 \\
\hline 57 & $\mathrm{I}-6-\mathrm{G}$ & 1.20 & 27.33 & 2.17 & 29.51 \\
\hline 58 & I-6-H & 2.20 & 44.37 & 3.83 & 48.20 \\
\hline 59 & I-6-I & 2.30 & 44.58 & 3.91 & 48.49 \\
\hline 60 & I-6-K & 0.45 & 13.10 & 1.01 & 14.10 \\
\hline 61 & I-7-A & 2.10 & 39.54 & 3.32 & 42.87 \\
\hline 62 & I-7-B & 2.60 & 50.58 & 4.20 & 54.79 \\
\hline 63 & I-7-C & 1.20 & 27.38 & 2.12 & 29.50 \\
\hline 64 & I-7-D & 1.60 & 31.21 & 2.56 & 33.78 \\
\hline 65 & I-7-E & 2.00 & 40.93 & 3.55 & 44.47 \\
\hline 66 & $\mathrm{I}-7-\mathrm{F}$ & 2.00 & 40.22 & 3.57 & 43.79 \\
\hline 67 & $\mathrm{I}-7-\mathrm{G}$ & 1.00 & 23.43 & 1.77 & 25.20 \\
\hline 68 & I-7-H & 0.40 & 16.87 & 0.95 & 17.83 \\
\hline 69 & I-7-I & 0.90 & 22.45 & 1.60 & 24.05 \\
\hline 70 & I-7-K & 1.50 & 28.86 & 2.66 & 31.52 \\
\hline 71 & $\mathrm{I}-8-\mathrm{A}$ & 2.30 & 46.38 & 4.03 & 50.41 \\
\hline 72 & I-8-B & 2.70 & 55.14 & 4.68 & 59.82 \\
\hline 73 & $\mathrm{I}-8-\mathrm{C}$ & 2.00 & 35.66 & 2.98 & 38.64 \\
\hline 74 & I-8-D & 1.70 & 36.75 & 3.14 & 39.89 \\
\hline 75 & I-8-E & 2.30 & 44.55 & 3.93 & 48.48 \\
\hline 76 & $\mathrm{I}-8-\mathrm{F}$ & 2.30 & 43.69 & 3.93 & 47.63 \\
\hline 77 & $\mathrm{I}-8-\mathrm{G}$ & 1.20 & 28.09 & 2.25 & 30.34 \\
\hline 78 & I-8-H & 0.90 & 24.26 & 1.72 & 25.98 \\
\hline 79 & I-8-I & 0.30 & 14.36 & 0.76 & 15.12 \\
\hline 80 & $\mathrm{I}-8-\mathrm{K}$ & 1.70 & 31.45 & 2.93 & 34.37 \\
\hline 81 & I-9-A & 1.80 & 37.02 & 3.06 & 40.08 \\
\hline 82 & I-9-B & 1.40 & 37.33 & 2.82 & 40.15 \\
\hline 83 & I-9-C & 1.90 & 35.99 & 3.02 & 39.01 \\
\hline
\end{tabular}


Continuation of Table A1

\begin{tabular}{|c|c|c|c|c|c|}
\hline 1 & 2 & 3 & 4 & 5 & 6 \\
\hline 84 & I-9-D & 1.50 & 29.27 & 2.36 & 31.62 \\
\hline 85 & I-9-E & 1.00 & 24.46 & 1.83 & 26.29 \\
\hline 86 & I-9-F & 1.00 & 23.28 & 1.80 & 25.08 \\
\hline 87 & I-9-G & 1.00 & 23.86 & 3.24 & 25.67 \\
\hline 88 & I-9-H & 1.70 & 38.78 & 2.88 & 42.02 \\
\hline 89 & I-9-I & 1.60 & 34.69 & 0.96 & 37.57 \\
\hline 90 & I-9-K & 0.45 & 12.61 & & 13.56 \\
\hline
\end{tabular}

5

[1] Ainsworth, B.E.; Haskell, W.L., Whitt, M.C., Irwin, M.L., Swartz, A.M., Strath, S.J., O'Brien, W.L., Bassett, D.R., Schmitz, K.H., Emplaincourt, P.O., Jacobs, D.R. and Leon, A.S., 2000. Compendium of Physical Activities: An Update of Activity Codes and MET Intensities. Medicine \& Science in Sports \& Exercise. Vol. 32 (9 Suppl), pp.498-504. CiteSeerX 10.1.1.524.3133. DOI: 10.1097/00005768-200009001-00009.

[2] Bajdor, P., Starostka-Patyk, M., 2021. Smart City: A Bibliometric Analysis of Conceptual Dimensions and Areas. Energies, Vol. 14, No. 14, p.4288. DOI: $10.3390 /$ en 14144288 .

[3] Balandina, I.S., Obolentseva, L.V., Aleksandrova, S.A., Polyakova, Y.O. and Dulfan, S.B., 2018. Assessing Corporate Culture of an Enterprise-based on Competing Values Framework Design. J. Advanced Res. L. \& Econ., Vol. 9, p.1176.

[4] Chornopyska, N., Bolibrukh, L., 2020. The Influence of the Covid-19 Crisis on the Formation of Logistics Quality. Intellectualization of Logistics and Supply Chain Management, Vol. 2, pp.88-98. DOI: $10.46783 /$ smart-scm/2020-2-7.

[5] Chortok, Y., Yevdokymova, A. and Serpeninova, Y., 2018. Formation of the Mechanism of Corporate Social and Environmental Responsibility of the Trading Company. Journal of Environmental Management \& Tourism, Vol. 9, No. 5(29), pp.1011-1018. DOI: 10.14505//jemt.9.5(29).13.

[6] Comi, A., 2020. A Modelling Framework to Forecast Urban Goods Flows. Research in Transportation Economics, Vol. 80, 100827. DOI: 10.1016/j.retrec.2020.100827.

[7] Fatoki, O., 2020. Factors Influencing the Purchase of Energy-Efficient Appliances by Young
Consumers in South Africa. Foundations of Management, Vol. 12, No. 1, pp.151-166. DOI: https://doi.org/10.2478/fman-2020-0012.

[8] Fesenko, T., Shakhov, A., Fesenko, G., Bibik, N. and Tupchenko, V., 2018. Modeling of Customer Oriented Construction Project Management Using the Gender Logic Systems. Eastern-European Journal of Enterprise Technologies, Vol. 1, No. 3, 91, pp.50-59. DOI: 10.15587/17294061.2018 .123124$.

[9] Galkin, A., Dolia, C. and Davidich, N., 2017. The Role of Consumers in Logistics Systems. Transportation Research Procedia, Vol. 27, pp.11871194. DOI: 10.1016/j.trpro.2017.12.010.

[10] Galkin, A., Mykola, K., Balandina, I., Anton, R., Litomin, I., Davidich, N., and Kumar, C., 2020. Assessing the Impact of Population Mobility on Consumer Expenditures While Shopping. Transportation Research Procedia, Vol. 48, pp.21872196. DOI: $10.1016 /$ j.trpro.2020.08.275

[11] Galkin, A., Obolentseva, L., Balandina, I., Kush, E., Karpenko, V., Bajdor, P., 2019a. Last-Mile delivery for consumer driven logistics. Transportation Research Procedia, Vol. 39, pp.74-83. DOI: 10.1016/j.trpro.2019.06.009.

[12] Galkin, A., Popova, Y., Bodnaruk, O., Zaika, Y., Chuprina, E., Shapovalenko and D. Kolonataievskyi, O., 2019b. Attractiveness Modeling of Retail on Emotional Fatigue of Consumers. The South East European Journal of Economics and Business, Vol. 14, No. 2, pp.106-116. DOI: 10.2478/jeb-2019-0017.

[13] Gorokhova, T., Mamatova, L., 2020. The Impact of e-Commerce Development on Logistic Service in Ukraine: Perspectives and Challenges. Intellectualization of Logistics and Supply Chain Management, Vol. 1, pp.76-90. DOI: 10.46783/smart$\mathrm{scm} / 2020-1-7$. 
[14] Halkin, A., 2018. Emotional State of Consumer in the Urban Purchase: Processing Data. Foundations of Management, Vol. 10, No. 1, pp.99-112. DOI: 10.2478/fman-2018-0009.

[15] Halkin, A., 2020. Assessing the Utility of Retailer Based on Generalized Costs of End-Consumers. Foundations of Management, Vol. 12, No. 1, pp.31-41. DOI: 10.2478/fman-2020-0003.

[16] Halkin, A., Bliumska-Danko, K., Smihunova, O., Dudnyk, E. and Balandina, I., 2019b. Investigation Influence of Store Type on Emotional State of Consumer in the Urban Purchase. Foundations of Management, Vol. 11, No. 1, pp.7-22. DOI: 10.2478/fman-2019-0001.

[17] Jetté, M., Sidney, K. and Blümchen, G., 1990. Metabolic Equivalents (METS) in Exercise Testing, Exercise Prescription, and Evaluation of Functional Capacity. Clinical Cardiology, 13(8), pp.555-565.

[18] Kolodii, S., 2020. Correlation-regression Analysis of GDP and Average Wage Indicators in Ukraine. Bulletin of the Cherkasy Bohdan Khmelnytsky National University. Economic Sciences, Vol. 1, pp.82-89. DOI: 10.31651/2076-58432020-1-82-89.

[19] Koval, L., Tserklevych, V., Popovich, O., Bukhta, S., Hurman, O. and Komarnitskyi, I., 2020. Gender Targeting of Restaurants' Visitors - Representatives of Generation Z. International Journal of Management (IJM), Vol. 11, No. 6, pp.155162. DOI: 10.34218/IJM.11.6.2020.014.

[20] Lusch, R.F., Serpkenci, R.R. and Orvis, B.T., 2015. Determinants of Retail Store Performance: A Partial Examination of Selected Elements of Retailer Conduct. In Proceedings of the 1995 World Marketing Congress, pp.495-504. Springer, Cham. DOI: 10.1007/978-3-31917311-5_69.

[21] Mifflin, M.D., St Jeor, S.T., Hill, L.A., Scott, B.J., Daugherty, S.A. and Koh, Y.O., 1990. A New Predictive Equation for Resting Energy Expenditure in Healthy Individuals. The American Journal of Clinical Nutrition, Vol. 51, No. 2, pp.241247. DOI: 10.1093/ajcn/51.2.241.

[22] Mixed-Use Properties: A Convenient Option for Shoppers. 2019. Access at: https://www.icsc.
com/uploads/t07-subpage/Mix_Use_Convenien ce_ConsumerSeries.pdf (Accessed 10.01.2021).

[23] Pursky, O., Selivanova, A., Dubovyk, T. and Herasymchuk, T., 2019. Software Implementa-tion of e-Trade Business Process Management Information System. In CEUR Workshop Proceedings, Vol. 2546, pp.171-181 Access at: https://www.semanticscholar.org/paper/Software -implementation-of-e-trade-business-processPursky-Selivanova/bd187760df0e52ec4d2cb2d dba984da954fb6bad\#paper-header.

[24] Russo, F., Comi, A., 2012. City Characteristics and Urban Goods Movements: A Way to Environmental transportation System in a Sustainable City. Procedia-Social and Behavioral Sciences, Vol. 39, pp.61-73. DOI: 10.1016/j.sbspro.2012. 03.091 .

[25] Selivanova, A., Pursky, O., Yurchenko, Y., Samoylenko, H. and Dubovyk, T., 2020. Agent Modeling of Online Store Activities. In IT\&I Workshops. December 0203, 2020, KNU Taras Shevchenko, Kyiv, Ukraine, pp.227-236. Access at: http://ceur-ws.org/Vol-2845/Paper_22.pdf.

[26] Sharma, P., Chen, I.S., Luk, S.T., 2018. Tourist Shoppers' Evaluation of Retail Service: A Study of Cross-border Versus International Outshoppers. Journal of Hospitality \& Tourism Research, Vol. 42, No. 3, pp.392-419. DOI: 10.1177/10963 48015584439.

[27] Verroios, V., Efstathiou, V. and Delis, A., 2011, June. Reaching Available Public Parking Spaces in Urban Environments Using ad hoc Networking. In Mobile Data Management (MDM), 2011 12th IEEE International Conference. Vol. 1, pp.141-151.

[28] Wodecki, A., 2020. The Reserve Price Optimization for Publishers on Real-Time Bidding on-Line Marketplaces with Time-Series Forecasting. Foundations of Management, Vol. 12, No. 1, pp.167-180. DOI: 10.2478/fman-2020-0013.

[29] Zatonatska, T., Dluhopolskyi, O., Chyrak, I. and Kotys, N., 2019. The Internet and e-Commerce Diffusion in European Countries (modeling at the example of Austria, Poland and Ukraine). Innovative Marketing, Vol. 15, No. 1, pp.66-75. DOI: 10.21511/im.15(1).2019.06. 